\title{
Nomophobia and Related Factors in Students of a Faculty of Humanities and Social Sciences
}

\section{Bir İnsani ve Sosyal Bilimler Fakültesi Öğrencilerinde Nomofobi ve illişkili Faktörlerin İncelenmesi}

\author{
(D) Edibe PİRINÇCİ, iD Fatma Nur KARAÇORLU, iD Ayşe Ferdane OĞUZÖNCÜL, id Süleyman Erhan DEVECİ
}

Fırat University Faculty of Medicine, Department of Public Health, Elazı̆̆, Turkey

\section{ABSTRACT}

Objective: Nomophobia is defined as the involuntary fear experienced by the individual when he/she cannot access his mobile device or cannot communicate on the mobile device. This study aimed to examine nomophobia and related factors in the first- and fourth-year students in the Department of Turkish Language and Literature and Western Languages and Literatures at the Faculty of Humanities and Social Sciences of Firat University.

Methods: In this cross-sectional study, a questionnaire survey including questions about sociodemographic features and smartphone use and nomophobia questionnaire (NMP-Q) was performed.

Results: Data were collected from 325 participants $(69.2 \%$ female), with an average age of $21.06 \pm 3.54$ years. The NMP-Q score was $73.21 \pm 26.60$ points. No significant difference was found between the genders according to the NMP-Q score $(p>0.05)$. Those carrying chargers, spending time with a smartphone before bedtime, and checking their smartphones as soon as they wake up had a higher NMP-Q score ( $\mathrm{p}<0.01)$. NMP-Q score increased with the increase in the duration of using smartphones, daily usage time, daily frequency of checking smartphones, and daily mobile internet usage time $(\mathrm{p}<0.001)$.

Conclusion: It may be helpful to delay the age of starting smartphone use as much as possible to reduce the level of nomophobia in university students since those who started using smartphones at an earlier age are more prone to nomophobia.

Keywords: Nomophobia, university, students, mobile phone

\section{ÖZ}

Amaç: Nomofobi, birey mobil cihazına erişemediğinde veya mobil cihaz üzerinde iletişim kuramadığında, bireyin yaşadığı istemsiz korku olarak tanımlanmaktadır. Bu araştırmada Fırat Üniversitesi İnsani ve Sosyal Bilimler Fakültesi Türk Dili ve Edebiyatı ile Batı Dilleri ve Edebiyatları Bölümleri’ndeki birinci ve dördüncü sınıftaki öğrencilerde nomofobi ve ilişkili faktörlerin incelenmesi amaçlanmıştır.

Yöntemler: Kesitsel tipte bir araştırmadır. Sosyo-demografik özellikler ve akıllı telefon kullanımı ile ilgili sorular ve nomofobi ölçeğinin yer aldığı bir anket formu uygulanmıştır.

Bulgular: Üç yüz yirmi beş öğrenciye ulaşılmıştır. Öğrencilerin \%69,2'si kadın olup, tüm öğrencilerin yaş ortalamaları $21,06 \pm 3,54$ 'tür. Öğrencilerin, Nomofobi ölçeği puanı 73,21 $\pm 26,60$ olarak saptanmıştır. Nomofobi ölçeği puanlarına göre cinsiyetler arasında istatistiksel olarak anlamlı bir fark bulunmamıştır ( $p>0,05)$. Yanında şarj aleti taşıyanların, yatmadan önce akıllı telefonla zaman geçirenlerin, uyanır uyanmaz akıllı telefonunu kontrol edenlerin daha yüksek nomofobi ölçeği puanına sahip olduğu bulunmuştur $(\mathrm{p}<0,01)$. Akıllı telefonu kullanma yılı, günlük kullanma süresi, günlük kontrol sıklığı, günlük mobil internet kullanım süresi arttıkça nomofobi ölçeği puanı artmaktadır ( $<<0,001)$.

Sonuç: Daha erken yaşta akıllı telefon kullanmaya başlayanlar nomofobiye daha yatkın olduğundan, üniversite öğrencilerinde görülen nomofobi düzeyini düşürmek için akıllı telefon kullanmaya başlama yaşını olabildiğince geciktirmeye çalışmak faydalı olabilir.

Anahtar Sözcülkler: Nomofobi, üniversite, öğrenciler, mobil telefon

Address for Correspondence: Fatma Nur KARAÇORLU, Fırat University Faculty of Medicine, Department of Public Health, Elazığ, Turkey

E-mail: fatmanurkaracorlu@hotmail.com ORCID ID: orcid.org/0000-0001-7907-2776 


\section{Introduction}

Nomophobia is a disorder of the contemporary digital and virtual society and is the result of the development of new technologies that enable virtual communication $(1,2)$. Developments in technology cause changes in culture. Culture can also affect a person's health-related behavior, as it is one of the factors that drive a person's behavior. To protect the health of individuals and to treat them while they are sick, it is necessary to know their behavior and the factors associated with their behavior (3). Therefore, nomophobia is a public health problem $(4,5)$.

Smartphones have become an important part of people's lives today owing to the developments in communication and information technologies. Nowadays, the use of smartphones is increasing in developed and developing countries (6). The number of smartphone users worldwide has now exceeded three billion. China, India, and the USA have the highest number of smartphone users and are likely to exceed 100 million users (7). As of 2018, there were 41.9 million smartphone users in Turkey. This number is expected to increase to 52.8 million by 2021 and 56.4 million by 2023 (8). According to the We Are Social Statistics of Turkey Electronic Device Use in 2019, 98\% of adults in Turkey were mobile phone users and $77 \%$ of these people prefer smartphones (9).

Smartphones are mainly used to access information, join social networks, increase social interactions, plan and organize jobs, access e-mails, shop online, and play games (10). Contrary to all these functions and benefits of smartphones, excessive use of smartphones can have negative consequences $(11,12)$. Especially, while young individuals benefit from the opportunities provided by smartphones, they become addicted within a short time and even experience phobia in case of deprivation (13). Nomophobia is the involuntary fear derived from the English word nomophobia ("no mobile phone" and phobia) and refers to the experience when a person cannot access or communicate on their mobile device $(1,14,15)$. Bragazzi et al. stated that nomophobia is a specific phobia and suggested its inclusion in the Diagnostic and Statistical Manual of Mental Disorders (5 ${ }^{\text {th }}$ Edition). They emphasized that nomophobia may be the forerunner of a more serious psychiatric disorder due to the tendency of psychiatric disorders to cluster together frequently $(2,16)$.

Typical features of nomophobic behaviors include continuously checking whether there are messages or calls, worrying and feeling anxious when the mobile phone is out of range or having restricted use, leaving their smartphone open for $24 \mathrm{~h}$, and going to the bed with a smartphone (2). Young people are more prone to using and adapting emerging technology and therefore more prone to nomophobia $(5,17,18)$. A study conducted on university students in Turkey found that $42.6 \%$ of the students had nomophobia. The same study found that gender and the duration of smartphone ownership had affected young adults' nomophobic behaviors, whereas age had no effect (19). In Turkey, another study conducted among university students revealed that the level of nomophobia was higher in women and those with younger age, but no relationship was found between smartphone use time and nomophobia level (20). Despite this information about nomophobia, evidence on this subject is limited. A systematic review about nomophobia published in 2020 emphasized that nomophobia was in the early stages of research since studies on nomophobia were mostly recent, quantitative, and cross-sectional and performed in a limited population (youth and university students). For this reason, most of the studies on nomophobia are in the discovery phase (5).

Because of the small number of studies and information about nomophobia, high prevalence among the young population, and nomophobia being an important psychiatric and public health problem, this study aimed to examine the nomophobia levels and factors related to nomophobia in students of a Faculty of Humanities and Social Sciences.

\section{Methods}

This cross-sectional study focused on 2,111 students at the Faculty of Humanities and Social Sciences, University of Firat, in the 2018-2019 academic year. The incidence of nomophobia was set as $42.6 \%$ (19), so the minimum number of people to be included in the study was 319 according to the following formula: $\mathrm{n}=\mathrm{Npqt}^{2} / \mathrm{d}^{2}(\mathrm{~N}-1)+\mathrm{pqt}^{2}(21)$, with the following values: $\mathrm{N}$ (universe size) $=2,111, \mathrm{p}$ (probability of occurrence of the event under investigation) $=0.426, \mathrm{q}$ (probability of occurrence of the event under investigation not seen) $=0.574, \mathrm{t}$ (theoretical value from the $t$ table at a certain degree of freedom and detected error level $)=1.96$, and $\mathrm{d}( \pm$ deviation to be made according to the frequency of occurrence of the event) $=0.05$.

The Faculty of Humanities and Social Sciences consisted of six departments. Each department was accepted as a cluster, and two departments from six departments were selected by drawing lots. Selected departments were Turkish Language and Literature, and Western Languages and Literatures. The first- and fourth-year students in selected departments were included in this study for comparison between the freshmen and seniors. There were 109 first-year students and 51 fourth-year students in the Department of Western Languages and Literature. Moreover, there were 84 first-year students and 91 fourth-year students in the Turkish Language and Literature Department. In total, there were 335 first- and fourth-year students in both departments. The target sample was 335 students, but 325 students were enrolled.

The study was performed after it was approved by Firat University Ethics Committee, and data collection was started in September 2018. The research ethics permission was obtained from Firat University Non-interventional Research Ethics Committee (date: 21/06/2018, no: 263000).

Data were collected using a researcher-developed questionnaire based on the results of the reviewed relevant literature. The questionnaire was tested through a pilot survey including 18 students, and necessary modifications were made based on the results. The survey was implemented under direct observation after the necessary explanations were made and informed consent was obtained. The survey form consists of two parts: the first section includes questions about demographic information 
form and smartphone use, and the second section includes the nomophobia questionnaire (NMP-Q).

Nomophobia Questionnaire: The scale was developed by Yıldırım and Correia (15) and adapted to Turkish by Yıldırım et al. (19), which consists of 20 items. It consists of a total of four subdimensions: "not being able to access information (4 items)," "losing connectedness (5 items)," "not being able to communicate (6 items)," and "giving up convenience (5 items)." Cronbach's alpha values of the original scale and the Turkish version of the scale were 0.94 and 0.92 , respectively. Cronbach's alpha values of the subdimensions were $0.82,0.81,0.93$, and 0.87 on the original scale and $0.94,0.91,0.90$, and 0.74 on the Turkish version of the scale. The confirmatory factor analysis results of the Turkish version of the scale were as follows: $\chi 2$ $(164)=469.90$, normed $\chi 2=2.86$, comparative fit index $=0.92$, and root mean square error of approximation $=0.08$. The Turkish NMP-Q was a valid and reliable measure of nomophobia. It is a 7-point Likert-type scale. Total scores are calculated by summing up responses to each item, resulting in a nomophobia score ranging from 20 to 140 , with higher scores corresponding to a more severe nomophobia. The nomophobia scale does not have a specific cut-off point.

\section{Statistical Analysis}

SPSS 21.0 package program (IBM Corp., Armonk, NY, USA) was used in data analysis and error checks, and tables and statistical analyses were made through this program. Depending on the nature of the variables in the statistical analysis, the following analyses were run: percentage, average, t-test, one-way analysis of variance, Tukey HSD, Pearson correlation analysis, and multiple linear regression analysis. Averages were calculated with standard deviation (mean \pm standard deviation), and $\mathrm{p}<0.05$ was accepted as the level of statistical significance.

\section{Results}

In this study, 69.2\% ( $\mathrm{n}=225$ people) of the included students were female students, and the average age of all students was $21.06 \pm 3.54$ [minimum $(\min )=17$, maximum $(\max )=42$ ] years. The socioeconomic level of $88.3 \%$ of the students $(n=287)$ was moderate, and $52.3 \%$ of students $(n=170)$ belonged to Turkish Language and Literature Department, and 56.6\% of the students $(n=184)$ were on the first class. Students' average duration of using smartphones, average daily smartphone usage time, average daily mobile internet usage time, and average age of starting using a smartphone were $4.78 \pm 2.37$ years, $5.65 \pm 3.86$ hours, $4.43 \pm 3.77$ hours, and $16.27 \pm 4.04$ years, respectively. The frequency of accessing social media via smartphone was as follows: $5.2 \%(\mathrm{n}=17)$, never; $11.4 \%(\mathrm{n}=37)$, rarely; $40.6 \%$ $(n=132)$, sometimes; $29.9 \%(n=97)$ often; and $12.9 \%(n=42)$, always.

Table 1 presents the scores on the NMP-Q and its subdimensions. The students' NMP-Q score was 73.21 \pm 26.60 ( $\min =20$, $\max$ $=140$ ). The scores on the subdimensions were as follows: not being able to access information, $16.04 \pm 7.34(\min =4, \max =$ $28)$; losing connectedness, $17.28 \pm 8.33$ ( $\min =5$, $\max =35)$; not being able to communicate, 26.19 \pm 11.11 ( $\min =6, \max =42)$; and giving up convenience, $13.98 \pm 8.53(\min =5, \max =35)$.

According to Table 2, the NMP-Q score did not differ significantly according to gender, socioeconomic level, and class $(\mathrm{p}>0.05)$. The NMP-Q score was significantly higher in the group aged $\leq 13$ years than in the other age groups. Those who see themselves as smartphone addicts, carry a charger with them, spend time with a smartphone before bedtime, leave their smartphones open at night, and check their smartphone as soon as they wake up had a higher NMP-Q score $(\mathrm{p}<0.05)$.

As shown in Table 3, the most frequent reason for smartphone use was to follow developments in the environment and agenda. In this study, $84.9 \%$ of the participants $(n=276)$ thought that an expensive smartphone is not a prestigious tool. NMP-Q scores were significantly higher in students who answered yes to the following statements about smartphone use: "It allows me to follow the developments on the agenda," "It gives me access to social media (Facebook, Twitter, etc.)," "Thanks to its functions, it allows me to play games easily," and "An expensive smartphone increases my prestige around me" $(\mathrm{p}<0.05)$.

Correlation coefficients between continuous variables are presented in Table 4. The NMP-Q score correlated negatively with age $(\mathrm{r}=-0.13, \mathrm{p}<0.01)$. Table 4 also indicates that the NMP-Q score correlated positively with the smartphone use duration $(\mathrm{r}=0.21)$, daily smartphone usage time $(\mathrm{r}=0.29)$, daily frequency of checking smartphone $(\mathrm{r}=0.27)$, and daily mobile internet usage time $(\mathrm{r}=0.34)$.

The results of the multiple linear regression analysis using NMP-Q score as the dependent variable are shown in Table 5. Variables such as age, duration of using a smartphone, daily smartphone usage time, daily frequency of checking smartphone, and daily mobile internet usage time contributed significantly to the model and explained 16\% of the change in the NMP-Q

Table 1. Students' scores on NMP-Q and its subdimensions

\begin{tabular}{|l|l|l|}
\hline NMP-Q and its subdimensions & M SD & Min-max \\
\hline Not being able to access information & $16.04 \pm 7.34$ & $4-28$ \\
\hline Losing connectedness & $17.28 \pm 8.33$ & $5-35$ \\
\hline Not being able to communicate & $26.19 \pm 11.11$ & $6-42$ \\
\hline Giving up convenience & $13.98 \pm 8.53$ & $5-35$ \\
\hline NMP-Q & $73.21 \pm 26.60$ & $20-140$ \\
\hline
\end{tabular}

SD: Standard deviation, Min: Minimum, Max: Maximum, NMP-Q: Nomophobia questionnaire 
Table 2. Some features of the students and NMP-Q scores according to these features

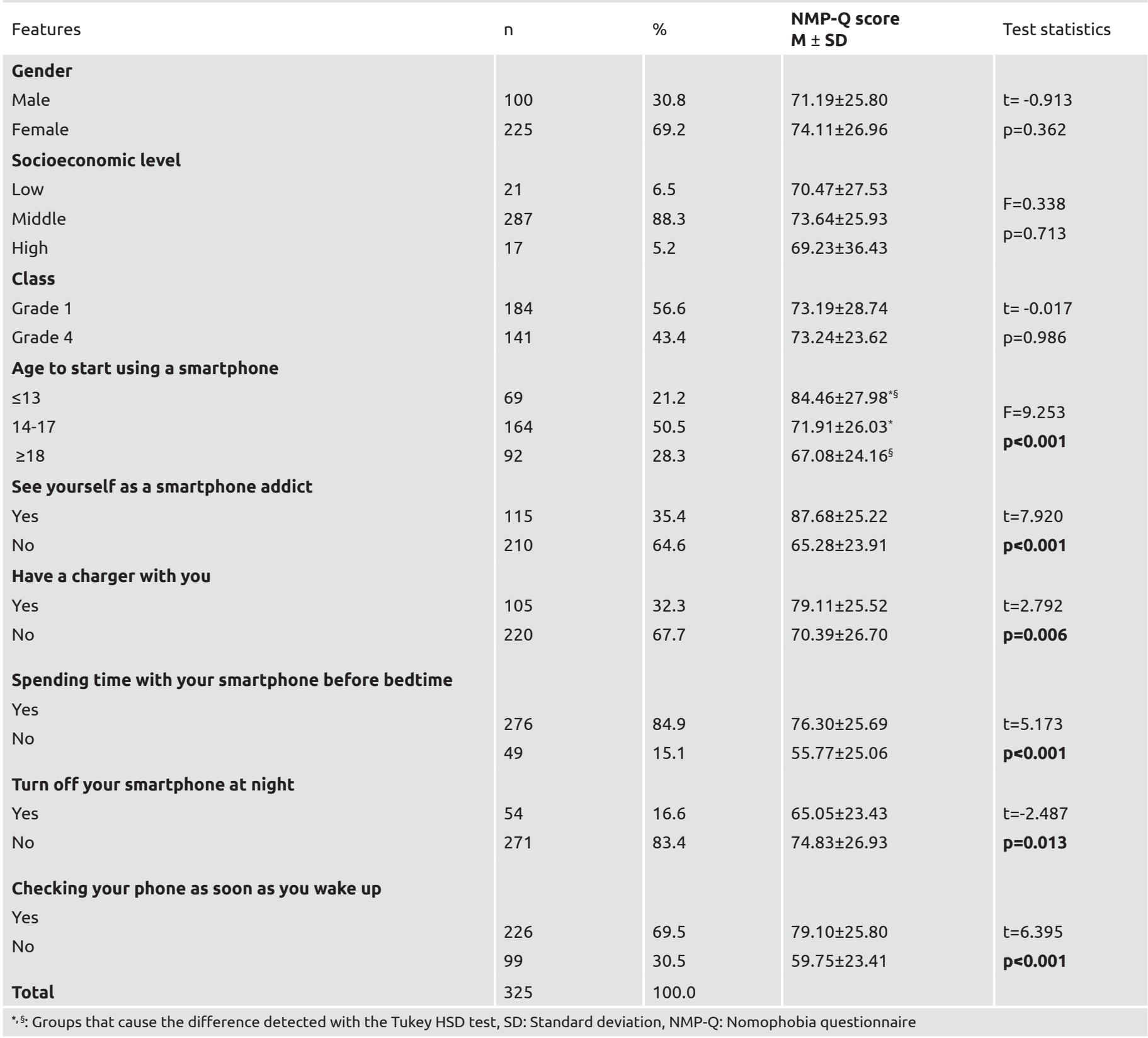

score. Daily mobile internet usage time contributed the most to the change in the NMP-Q score $(\mathrm{B}=2.07, \mathrm{p}<0.01)$.

\section{Discussion}

The NMP-Q score of the students was calculated as 73.21 \pm 26.60 (Table 1). Similarly, in a study conducted by Aş1k (22) on vocational college students in Turkey, the NMP-Q score was 72.09. Additionally, the NMP-Q score was 79.71 in the study conducted by Gezgin (23) on university students in Turkey. In addition, the NMP-Q score was $74.65 \pm 18.80$ in a study conducted on adolescents in Iran (24). Furthermore, it was $67.31 \pm 25.70$ in a study conducted on adolescents in Spain (25) and $82.39 \pm 18.63$ in a study conducted on nursing students in Spain (26). In national and international studies on nomophobia, university students have similar levels of nomophobia. This finding is compatible with those of the present study.

In the present study, although the NMP-Q score was higher in female students than in male students, they did not differ significantly (Table 2). Likewise, no significant relationship has been found between gender and nomophobia in many studies (13,27-32). Contrary to our findings, some studies have revealed that the level of nomophobia was significantly higher in women than in men $(19,20,26,33-36)$. With the difference in the findings, further studies are needed to investigate the effect of gender on individuals' susceptibility to nomophobia.

No difference was found between the NMP-Q scores of the students according to their socioeconomic levels (Table 2). 
Table 3. Students' purposes of using a smartphone and NMP-Q scores according to the purposes of using the smartphone

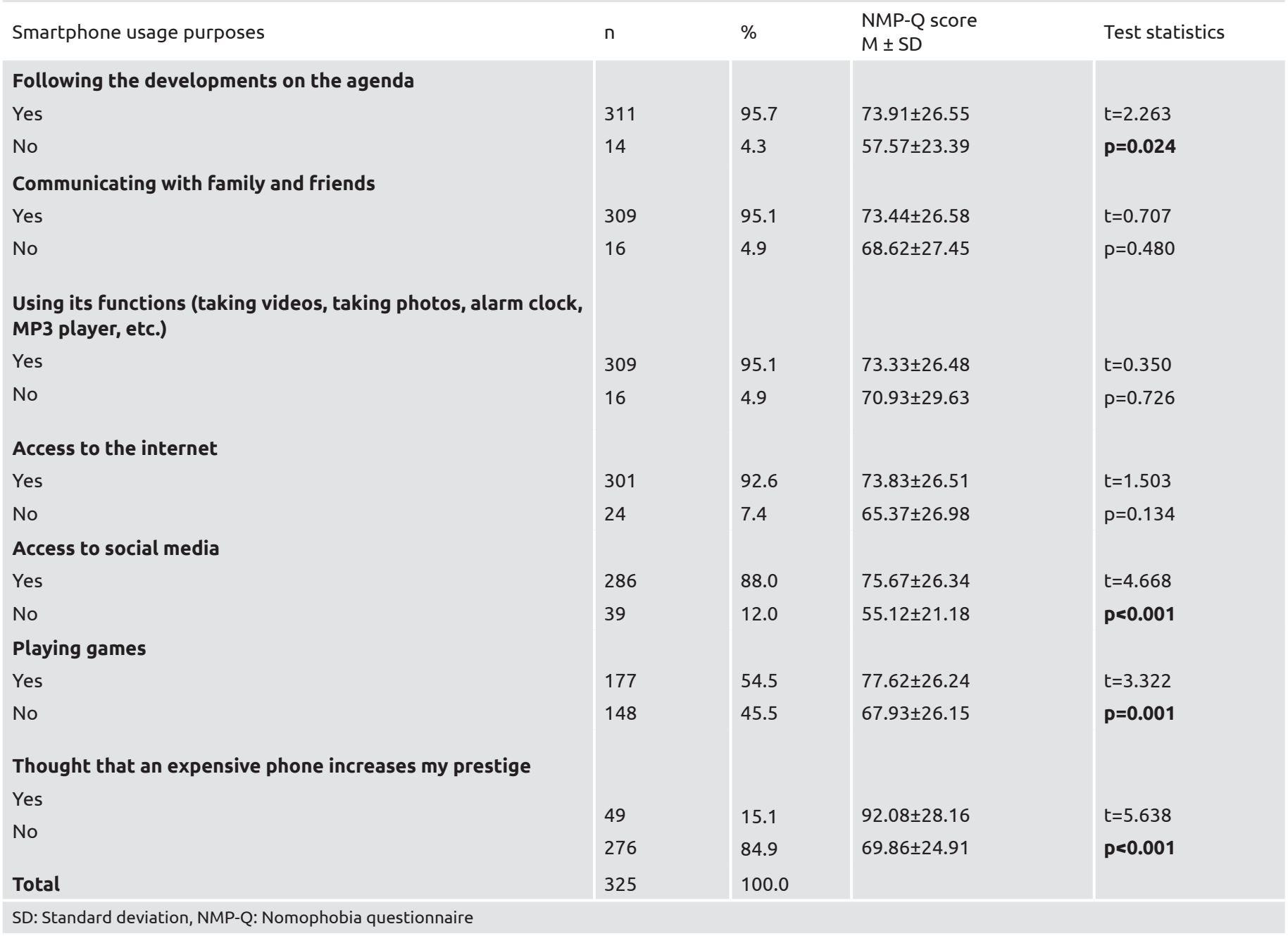

This finding is supported by a study conducted on high school students in Turkey, in which the NMP-Q score did not change according to the socioeconomic level (36). The widespread use of smartphones, in both developing and developed countries (6), may explain why nomophobia did not differ according to the socioeconomic level.

The NMP-Q score was higher in those who carry a charger with them, spend time with a smartphone before bedtime, leave their smartphone on at night, and use their smartphone as soon as they wake up (Table 2). Similar results were reported in other studies conducted in Turkey (36-38). These results suggest that individuals with nomophobia have features such as having a charger with them, spending time with a smartphone before bedtime, leaving their smartphone open at night, and using the smartphone as soon as they wake up.

NMP-Q scores were significantly higher in those who use their smartphone to follow the agenda, access social media, and play games (Table 3). In studies conducted on high school students and vocational college students in Turkey, the NMP-Q score was significantly higher in students who use their smartphones to connect to social media in parallel with our finding $(36,37)$. The increasing use of social media has made these platforms a part of life, leading to anxiety in situations when social media is not accessible. Therefore, excessive use of social media is considered a nomophobic behavior (39).

As the ages of the students increased, the NMP-Q score decreased (Table 4). Some studies can support this finding. For example, in a study of university students and public employees in Turkey, Erdem et al. reported a negative relationship between age and NMP-Q score (34). In addition, Gurbuz et al. (29) examined 17-29-year-olds and Gezgin et al. (20) evaluated students of the Faculty of Education in Turkey and showed that the NMP-Q score decreased with increasing age. This negative relationship is also supported by multiple linear regression analysis, which shows that age is a negative predictor of the nomophobia scale score (Table 5). By contrast, other studies in university students have found no significant relationship between age and NMP-Q scores $(19,26-28,30,33,40)$. The contradictory findings related to age in all these studies may be due to the limited age range of university students analyzed and the age ranges of these samples 
Table 4. Pearson correlation coefficients among continuous variables

\begin{tabular}{|c|c|c|c|c|c|c|}
\hline Variables & 1 & 2 & 3 & 4 & 5 & 6 \\
\hline 1. NMP-Q score & 1 & & & & & \\
\hline 2. Age & $-0.13^{* *}$ & & & & & \\
\hline 4. Daily smartphone usage time & $0.29^{* \star *}$ & $-0.17^{* *}$ & $0.23^{* * *}$ & & & \\
\hline 5. Daily frequency of checking smartphones & $0.27^{* * *}$ & -0.08 & $0.11^{*}$ & $0.48^{* * *}$ & & \\
\hline
\end{tabular}

Table 5. Multiple linear regression analysis predicting the NMP-Q score

\section{Variables}

Age

Duration of using a smartphone

Daily smartphone usage time

Daily frequency of checking smartphones

Daily mobile internet usage time

Model $R^{2}=0.16, p<0.001$, NMP-Q: Nomophobia questionnaire

were insufficient to distinguish nomophobia among age groups (30).

The present study shows that as the duration of smartphone use increased, the NMP-Q score increased (Table 4). The same result was found in the studies carried out in Turkey by Yıldirım et al. (19), Gezgin et al. (20), and Sirakaya (37). Furthermore, the duration of smartphone use is a positive predictor of the nomophobia scale score (Table 5) (41). However, some studies have not found a significant relationship between the duration of smartphone use and NMP-Q score $(23,28,42,43)$. In the present study, the NMP-Q score increased as the students' daily smartphone use time increased (Table 4). This finding is consistent with the literature $(28,36)$. As the daily smartphone usage time increases, the NMP-Q score also increased. The NMP-Q score increased with increasing daily frequency of checking smartphone (Table 4). Similarly, several studies have found that as the daily frequency of smartphone checks increases, the NMP-Q score significantly increases $(37,38,42,43)$. In addition, the multivariate analysis showed that the daily frequency of smartphone checks is a positive predictor of the nomophobia scale score (Table 5). Individuals who have high mobile internet usage during the day had higher NMP-Q scores (Table 4). Likewise, other studies have found a significant relationship between daily mobile internet usage time and NMP-Q score $(37,42,43)$. In addition to its positive contribution to the change in the nomophobia scale score, the duration of daily mobile internet usage made the most contribution in the model (Table 5). Accordingly, daily mobile internet usage appears to be the most important predictor of nomophobia (23).

\section{Study Limitations}

This study has some limitations. For example, the small sample size prevents the generalization of the results of this study.

\begin{tabular}{|l|ll|}
\hline B & SH B & $P$ \\
\hline-0.82 & 0.39 & 0.039 \\
1.61 & 0.60 & 0.008 \\
-0.56 & 0.72 & 0.439 \\
0.08 & 0.03 & 0.017 \\
2.07 & 0.75 & 0.006 \\
\hline
\end{tabular}

Therefore, more comprehensive and multicenter studies are needed regarding the factors that affect the levels of nomophobia and the behavior of individuals with nomophobia. Since the nomophobia scale used in the study did not have a cut-off point, the frequency of nomophobia among students and the levels of nomophobia of students could not be determined.

\section{Conclusion}

This study identified behaviors of individuals with nomophobia, such as seeing oneself as a smartphone addict, always carrying a charger, spending time with a smartphone before going to sleep, not turning off the smartphone while sleeping, using the smartphone upon waking up, using the smartphone to follow current developments, using it to access social media, using a smartphone for gaming, and believing that an expensive phone will increase a person's prestige. The level of nomophobia increases as the duration of smartphone use, daily smartphone usage time, daily frequency of checking the smartphone, and daily mobile internet usage increases and as age decreases. Although age is a negative predictor of nomophobia, duration of smartphone use, daily frequency of checking smartphone, and daily mobile internet usage time are positive predictors of nomophobia. Daily mobile internet usage time contributes most to the change in the nomophobia score. Since those who started using smartphones at an earlier age are more prone to nomophobia, it may be beneficial to try to delay the age of start using smartphones as much as possible to reduce the level of nomophobia as seen in university students. These issues should be considered to raise awareness about behavioral addiction types such as nomophobia in health education given to the public within the scope of preventive medicine to prevent nomophobia. Society should be conscious about the rational and correct use of technology. Healthcare providers, parents, and teachers can play a key role in 
these matters. For this reason, our work on university students, who will be the parents and teachers of the future, is valuable. Future studies of the relationship among nomophobia, quality of life, health behavior, and physical activity may help in further clarifying the nature of nomophobia.

\section{Ethics}

Ethics Committee Approval: The study was performed after it was approved by Firat University Ethics Committee, and data collection was started in September 2018. The research ethics permission was obtained from Firat University NonInterventional Research Ethics Committee (date: 21/06/2018, no: 263000).

Informed Consent: Obtained.

Peer-review: Externally peer reviewed.

\section{Authorship Contributions}

Concept: E.P., F.N.K., A.F.O., S.E.D., Design: E.P., F.N.K., A.F.O., S.E.D., Data Collection or Processing: E.P., F.N.K., Analysis or Interpretation: E.P., F.N.K., Literature Search: E.P., F.N.K., Writing: E.P., F.N.K., A.F.O., S.E.D.

Conflict of Interest: No conflict of interest was declared by the authors.

Financial Disclosure: The authors declared that this study received no financial support.

\section{References}

1. King AL, Valença AM, Nardi AE. Nomophobia: the mobile phone in panic disorder with agoraphobia: reducing phobias or worsening of dependence? Cogn Behav Neurol 2010;23:52-4.

2. Bragazzi NL, Del Puente G. A proposal for including nomophobia in the new DSM-V. Psychol Res Behav Manag 2014;7:155-60.

3. Fişek NH. Halk Sağlığı’na Giriş. 1st ed. Ankara: Çağ Matbaası; 1983.

4. Basu S, Garg S, Singh MM, Kohli C. Addiction-like Behavior Associated with Mobile Phone Usage among Medical Students in Delhi. Indian J Psychol Med 2018;40:446-51.

5. Rodríguez-García AM, Moreno-Guerrero AJ, López Belmonte J. Nomophobia: An Individual's Growing Fear of Being without a Smartphone-A Systematic Literature Review. Int J Environ Res Public Health 2020;17:580.

6. Lian L, You X, Huang J, Yang R. Who overuses smartphones? Roles of virtues and parenting style in smartphone addiction among Chinese college students. Comput Human Behav 2016;65:92-9.

7. O’Dea S. Number of smartphone users worldwide from 2016 to 2021 2020 [updated 10.06.2020. Available from: https://www.statista. com/statistics/330695/number-of-smartphone-users-worldwide/.

8. O'Dea S. Forecast of the smartphone user penetration rate in Turkey from 2018 to 20242020 [updated 10.06.2020. Available from: https://www.statista.com/statistics/568281/predicted-smartphoneuser-penetration-rate-in-turkey/.
9. We Are Social. Türkiye elektronik cihaz kullanım istatistikleri 2019 [updated 10.06.2020. Available from: https://wearesocial.com/ global-digital-report-2019.

10. Park N, Kim Y-C, Shon HY, Shim H. Factors influencing smartphone use and dependency in South Korea. Comput Human Behav 2013;29:1763-70.

11. Soni R, Upadhyay R, Jain M. Prevalence of smart phone addiction, sleep quality and associated behaviour problems in adolescents. International Journal of Research in Medical Sciences 2017;5:515.

12. Pearson C, Hussain Z. Smartphone addiction and associated psychological factors. Addicta 2016;3:193-207.

13. Erdem H, Kalkın G, Türen U, Deniz M. Üniversite öğrencilerinde mobil telefon yoksunluğu korkusunun (nomofobi) akademik başarıya etkisi. Süleyman Demirel Üniversitesi İktisadi ve İdari Bilimler Fakültesi Dergisi 2016;21:923-36.

14. King ALS, Valença AM, Silva ACO, Baczynski T, Carvalho MR, Nardi AE. Nomophobia: Dependency on virtual environments or social phobia? Comput Human Behav 2013;29:140-4.

15. Yıldırım C, Correia AP. Exploring the dimensions of nomophobia: Development and validation of a self-reported questionnaire. Comput Human Behav 2015;49:130-7.

16. Kamibeppu K, Sugiura H. Impact of the mobile phone on junior high-school students' friendships in the Tokyo metropolitan area. Cyberpsychol Behav 2005;8:121-30.

17. Darvishi M, Noori M, Nazer MR, Sheikholeslami S, Karimi E. Investigating Different Dimensions of Nomophobia among Medical Students: A Cross-Sectional Study. Open Access Maced J Med Sci 2019;7:573-8.

18. Musa R, Janiffa S, Rahman S. Who's at risk for smartphone nomophobia and pathology; the young or matured urban millennials? Advanced Science Letters 2017;23:7486-9.

19. Yıldırım C, Şumuer E, Adnan M, Yıldırım S. A growing fear: Prevalence of nomophobia among Turkish college students. Information Development 2016;32:1322-31.

20. Gezgin DM, Şumuer E, Arslan O, Yıldırım S. Nomophobia prevalence among pre-service teachers: A case of Trakya University. Trakya Üniversitesi Eğitim Fakültesi Dergisi 2017;7.

21. Sümbüloğlu K, Sümbüloğlu V. Biyoistatistik. 8th ed. Ankara: Hatiboğlu Yayınevi; 1988.

22. Aşık NA. Aidiyet duygusu ve nomofobi ilişkisi: Turizm öğrencileri üzerinde bir araştırma. Turar Turizm Araştırma Dergisi 2018;7:2442.

23. Gezgin DM. Exploring the influence of the patterns of mobile internet use on university students' nomophobia levels. European Journal of Education Studies 2017;3:29-53.

24. Lin CY, Griffiths MD, Pakpour AH. Psychometric evaluation of Persian Nomophobia Questionnaire: Differential item functioning and measurement invariance across gender. J Behav Addict 2018;7:100-8.

25. González-Cabrera J, León-Mejía A, Pérez-Sancho C, Calvete E. Adaptation of the Nomophobia Questionnaire (NMP-Q) to Spanish in a sample of adolescents. Actas Esp Psiquiatr 2017;45:137-44. 
26. Aguilera-Manrique G, Márquez-Hernández VV, Alcaraz-Córdoba T, Granados-Gámez G, Gutiérrez-Puertas V, Gutiérrez-Puertas L. The relationship between nomophobia and the distraction associated with smartphone use among nursing students in their clinical practicum. PLoS One 2018;13:e0202953.

27. Öz H, Tortop HS. Üniversite okuyan genç yetişkinlerin mobil telefon yoksunluğu korkusu (nomofobi) ile kişilik tipleri arasındaki ilişkinin incelenmesi. Yeni Medya Elektronik Dergisi 2018;2:146-59.

28. Adnan M, Gezgin DM. Modern çağın yeni fobisi: Üniversite öğrencileri arasında nomofobi prevalansı. Ankara Üniversitesi Eğitim Bilimleri Fakültesi Dergisi 2016;49:141-58.

29. Gurbuz IB, Ozkan G. What is Your Level of Nomophobia? An Investigation of Prevalence and Level of Nomophobia Among Young People in Turkey. Community Ment Health J 2020;56:814-22.

30. Apak E, Yaman ÖM. Üniversite öğrencilerinde nomofobi yaygınlığı ve nomofobi ile sosyal fobi arasındaki ilişki: Bingöl Üniversitesi örneklemi. Addicta: The Turkish Journal on Addictions 2019;6:61129.

31. Yavuz M, Altan B, Bayrak B, Gündüz M, Bolat N. The relationships between nomophobia, alexithymia and metacognitive problems in an adolescent population. Turk J Pediatr 2019;61:345-51.

32. Uysal Ş, Özen H, Madenoğlu C. Social Phobia in Higher Education: The Influence of Nomophobia on Social Phobia. The Global e-Learning Journal 2016;5:1-8.

33. Cain J, Malcom DR. An Assessment of Pharmacy Students' Psychological Attachment to Smartphones at Two Colleges of Pharmacy. Am J Pharm Educ 2019;83:7136.

34. Türen U, Erdem H, Kalkın G. No Mobile Phone Phobia (Nomophobia) Prevalence: Samples of Undergraduate Students and Public Employees from Turkey. International Journal of Informatics Technologies 2017;10:1-12.
35. Arpaci I, Baloğlu M, Özteke Kozan Hİ, Kesici Ş. Individual Differences in the Relationship Between Attachment and Nomophobia Among College Students: The Mediating Role of Mindfulness. J Med Internet Res 2017;19:e404.

36. Eren B, Kılıç ZN, Günal SE, Kırcalı MF, Öznacar BB, Topuzoğlu A. Lise öğrencilerinde nomofobinin ve ilişkili etkenlerin değerlendirilmesi. Anadolu Psikiyatri Derg 2020;21:133-40.

37. Sırakaya M. Ön lisans öğrencilerinin nomofobi düzeylerinin akıllı telefon kullanım durumlarına göre incelenmesi. Mersin Üniversitesi Eğitim Fakültesi Dergisi 2018;14:714-27.

38. Kaplan-Akıllı G, Gezgin DM. Üniversite öğrencilerinin nomofobi düzeyleri ile farklı davranış örüntülerinin arasındaki ilişkilerin incelenmesi. Mehmet Akif Ersoy Üniversitesi Eğitim Fakültesi Dergisi 2016;40:51-69.

39. Durak HY. What would you do without your smartphone? Adolescents' social media usage, locus of control, and loneliness as a predictor of nomophobia. Addicta: The Turkish Journal on Addictions. 2018;5:543-57.

40. Sethia S, Melwani V, Melwani S, Priya A, Gupta M, Khan A. A study to assess the degree of nomophobia among the undergraduate students of a medical college in Bhopal. Int J Community Med and Public Health 2018;5:2442-5.

41. Gonçalves S, Dias P, Correia A-P. Nomophobia and lifestyle: smartphone use and its relationship to psychopathologies. Computers in Human Behavior Reports 2020;2:100025.

42. Gezgin D, Şahin YL, Yıldırım S. Sosyal ağ kullanıcıları arasında nomofobi yaygınlığının çeşitli faktörler açısından incelenmesi. Eğitim Teknolojisi Kuram ve Uygulama 2017;7:1-15.

43. Gezgin DM, Hamutoğlu NB, Sezen-Gültekin G, Ayas T. The relationship between nomophobia and loneliness among Turkish adolescents. International Journal of Research in Education and Science 2018;4:358-74. 